\title{
COST MINIMIZATION ANALYSIS (CMA) ANTIBIOTIKA PASIEN INFEKSI SALURAN KEMIH (ISK) DI RSUD KOTA SAMARINDA
}

\author{
Siti Sulaeha*, Mirhansyah Ardana, Nurul Annisa \\ Laboratorium Penelitian dan Pengembangan Kefarmasian "Farmaka Tropis", \\ Fakultas Farmasi, Universitas Mulawarman, Samarinda, Indonesia \\ *Email: sitisulaehaaaaa@gmail.com
}

\begin{abstract}
ABSTRAK
Infeksi Saluran Kemih (ISK) merupakan suatu istilah yang menggambarkan adanya infeksi melibatkan saluran kemih yang umumnya disebabkan oleh bakteri Escherichia coli. Penggunaan antibiotika pada pasien yang berbeda dapat memberikan biaya yang berbeda beda juga, dimana dengan biaya yang telah dikeluarkan tersebut belum tentu menjamin efektivitas kesembuhan pasien. Penelitian ini bertujuan untuk menganalisis biaya yang dikeluarkan dan efektivitas penggunaan antibiotika ISK menggunakan analisis Farmakoekonomi dengan metode Cost Minimization Analysis (CMA). Penelitian ini merupakan penelitian deskriptif non eksperimental dan dilakukan secara retrospektif menggunakan data rekam medik pasien ISK di RSUD Kota Samarinda periode Januari 2017 - Juni 2018. Hasil penelitian menunjukan bahwa antibiotika pasien ISK yang paling banyak digunakan adalah seftriakson dan siprofloksasin, analisis menunjukkan bahwa biaya perawatan pasien dengan seftriakson sebesar Rp.3.600.138,- dan siprofloksasin sebesar Rp.3.635.140,-. Dari hasil tersebut menunjukan bahwa biaya yang dikeluarkan cenderung sama, maka dibutuhkan evaluasi ekonomi lain untuk menilai ke efektivan antibiotika dengan metode Cost Effective Analysis (CEA).
\end{abstract}

Kata Kunci: ISK, antibiotika, farmakoekonomi, CMA

\begin{abstract}
Urinary Tract Infection (UTI) are terms that are suitable for infections found by Escherichia coli bacteria. The used of antibiotics in different patients can provide different costs, with costs incurred that are not necessarily in accordance with the recovery of the patient. This study aims to analyze the costs and minimum used of antibiotics in UTI patients used Pharmacoeconomic analysis used the Cost Minimization Analysis (CMA) method. This research is a descriptive study and can be done retrospectively used medical record data of UTI patients at Samarinda city Hospital in January 2017 - June 2018. The results showed that the most widely used antibiotics for UTI patients were ceftriaxone and ciprofloxacin, the analysis showed that the cost of treating patients with ceftriaxone of Rp.3.600.138 and ciprofloxacin was Rp.3.635.140. From these results indicate that the costs incurred tend to be the same, it requires an economic evaluation to assess the effectiveness of antibiotics with the CEA method.
\end{abstract}


Keywords: UTI, antibiotics, pharmacoeconomic, CMA

DOI: https://doi.org/10.25026/mpc.v8i1.316

\section{PENDAHULUAN}

Infeksi saluran kemih (ISK) merupakan penyakit yang disebabkan karena adanya patogen pada saluran kemih, termasuk kandung kemih, prostat, ginjal dan saluran pengumpul. Sebagian besar ISK disebabkan oleh bakteri. Infeksi ISK merupakan infeksi bakteri paling umum dimana setiap tahunnya terjadi 150 juta kasus di seluruh dunia. Pada tahun 2007 di Amerika Serikat, ada sekitar 10,5 juta kasus untuk gejala ISK dan 2-3 juta kunjungan gawat darurat dengan menghabiskan biaya sekitar 3,5 juta dollar amerika per tahunnya [1]. Berdasarkan WHO dimana kasus ISK mencapai 25 juta tiap tahunnya, sedangkan di Indonesia sendiri banyak ditemui dengan 2 juta kasus tiap tahunnya [2].

Data penelitian epidemologi klinik melaporkan $25-35 \%$ perempuan dewasa pernah mengalami ISK. Pada masa neonatus, ISK lebih banyak terdapat pada bayi laki-laki (2,7\%) yang tidak menjalani sirkumsisi dari pada bayi perempuan $(0,7 \%)$, sedangkan pada masa anak-anak hal tersebut terbalik dengan ditemukannya angka kejadian sebesar 3\% pada anak perempuan dan $1 \%$ pada anak laki-laki. Insiden infeksi saluran kemih ini pada usia remaja anak perempuan meningkat 3,3\% sampai 5,8\% [3].

Penggunaan antibiotika adalah pilihan utama dalam pengobatan infeksi saluran kemih. Pemakaian antibiotika yang tidak sesuai dari prinsip dan pemakaian antibiotika secara tidak rasional dapat membawa dampak negatif kepada pasien dimana memungkinkan untuk meningkatnya resistensi dan efek samping yang tidak diinginkan [4].
Beberapa tahun belakangan biaya kesehatan banyak menarik perhatian beberapa masyarakat, seperti biaya rumah sakit, dokter, obat, dan lain-lainnya. Biaya yang telah dikeluarkan pun belum tentu menjamin keefektivitasan kesembuhan pasien. Untuk itu, perlu dilakukan analisis ekonomi yang terkait dengan pelayanan kesehatan yaitu CEA (cost-effectiveness analysis) dan CMA (cost-minimization analysis). Ilmu mengenai farmakoekonomi ini telah ditetapkan sebagai deskripsi dan analisis biaya terapi obat untuk sistem kesehatan dan sosial. Informasi ini dapat membantu dalam pemilihan terapi yang lebih efektif dengan harga seminimal mungkin. Dalam hal ini penelitian yang dilakukan akan membandingkan terapi antibiotika penyakit ISK menggunakan metode CMA (Cost Minimal Analysis) dan CEA (Cost Effective Analysis) [1,4].

\section{METODOLOGI PENELITIAN}

\section{Tempat dan Waktu}

Penelitian dilakukan di RSUD Kota Samarinda periode Januari 2017Juni 2018 di bagian Rekam Medis dan Bagian Keuangan.

\section{Jenis Penelitian}

Penelitian ini dilakukan dengan rancangan deskriptif melalui penelusuran data secara retrospektif dari data rekam medik pasien Infeksi Saluran Kemih (ISK) RSUD Kota Samarinda.

\section{Populasi dan Sampel Penelitian}

Populasi dalam penelitian ini adalah pasien ISK yang menjalani pengobatan di RSUD Kota Samarinda periode Januari 2017 - Juni 2018. Sedangkan sampel 
dalam penelitian ini adalah pasien yang sesuai dengan kriteria inklusi dan kriteria ekslusi.

Kriteria Inklusi:

1. Diagnosa ISK

2. Berusia $\geq 18$ tahun

3. Menggunakan terapi antibiotika

4. Pengguna jaminan sosial

Kriteria ekslusi:

Pasien ISK dengan komplikasi penyakit

\section{Analisis Data}

Perhitungan analisis Cost Minimization (CMA) dilakukan dengan menjumlahkan biaya direct cost dan indirect cost. Direct cost merupakan biaya yang dikeluarkan langsung dimana berhubungan dengan perawatan kesehatan, sedangkan indirect cost merupakan biaya yang berkaitan dengan hilangnya produktivitas akibat menderita suatu penyakit.

$$
D C+I C
$$

Keterangan :

DC: Direct cost

IC: Indirect cost

\section{HASIL DAN PEMBAHASAN}

Berdasarkan hasil penelusuran rekam medik pasien periode Januari 2017-Juni 2018 dimana didapatkan total 520 pasien. Dalam penelitian ini pasien yang diteliti adalah pasien yang menjalani rawat inap di beberapa RSUD Kota Samarinda sehingga dari pasien tersebut sebanyak 179 pasien merupakan pasien rawat inap pada tahun 2017 dan 25 pasien tahun 2018. Dari pasien yang menjalani rawat inap terdapat beberapa kriteria inklusi diantaranya pasien dengan jaminan sosial, pengguna antibiotika, berusia $\geq 18$ tahun, dan menggunakan antibiotika tunggal sebagai terapi.

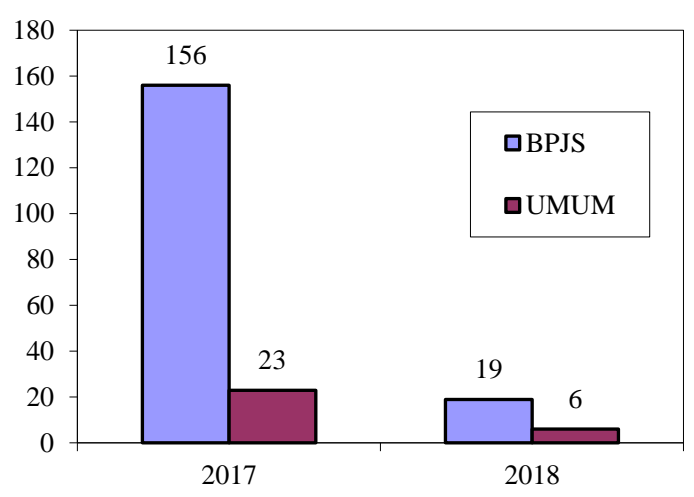

Gambar 1. Identifikasi Pasien Berdasarkan Jaminan Sosial.

\section{Karakteristik Pasien}

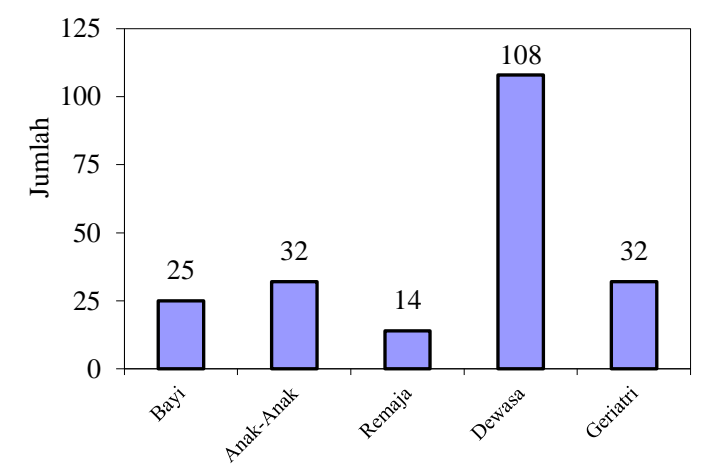

Gambar 2. Karakteristik Pasien berdasarkan Usia

Pasien ISK dikelompokan menjadi 5 kelompok usia yaitu kelompok usia 1 bulan-2 tahun untuk bayi atau infant, kelompok usia 3-11 tahun untuk anak-anak atau children, kelompok usia 12-18 tahun untuk remaja atau adolescent, kelompok usia 19-65 untuk dewasa atau adult, dan kelompok usia 65 tahun untuk geriatri. Sebanyak 12,2\% pasien dari kelompok bayi, $15,6 \%$ pasien dari kelompok anakanak, $52,9 \%$ pasien dari kelompok dewasa, dan sisanya $15,6 \%$ pasien dari kelompok geriatri. Hasil menunjukan 
bahwa kasus ISK banyak terjadi pada kelompok dewasa dengan rentang usia 19-65 tahun, hal ini dapat terjadi dikarenakan beberapa hal misalnya adanya infeksi yang menyerang akibat aktivitas seksual yang tinggi.

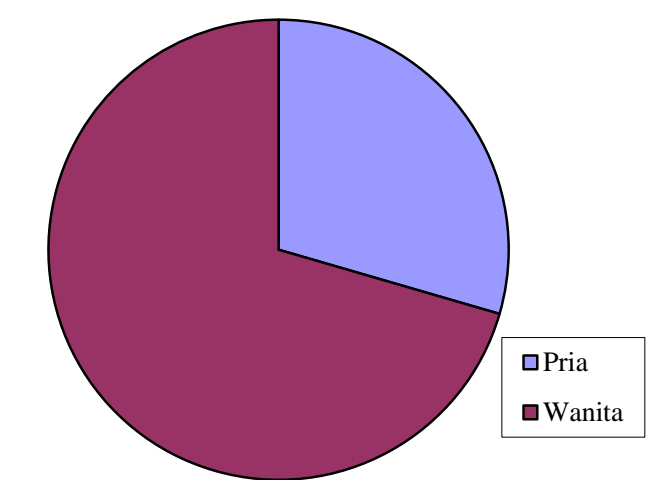

Gambar 3. Karakteristik Pasien Berdasarkan Jenis Kelamin

Berdasarkan jenis kelamin menunjukan bahwa wanita lebih banyak terinfeksi ISK dibanding pria dengan perbandingan $70,5 \%$ dan $29,5 \%$, hal ini terjadi lebih berisiko pada wanita dibanding dengan pria dikarenakan pada wanita memiliki saluran uretra yang lebih pendek dari pria sehingga dapat menyebabkan mikroorganisme seperti Escherichia coli masuk dan menginfeksi dengan cepat [6]. Wanita dan pria memiliki uretra yang berbeda, pada wanita memiliki panjang $3 \mathrm{~cm}$ dan membentang dari kandung kemih sampai lubang diantara labia minora sekitar 2,5 $\mathrm{cm}$ dibelakang kltoris. Pada pria memiliki panjang sekitar $20 \mathrm{~cm}$ dan membentang dari kandung kemih sampai ujung penis [7].

\section{Penggunaan Antibiotika Monoterapi}

Tabel 1. Antibiotika Monoterapi yang diberikan pada pasien ISK di RSUD Kota Samarinda

\begin{tabular}{|c|c|c|}
\hline Antibiotika & Jumlah & Persentase \\
\hline Golongan kuinolon & \multirow{4}{*}{2} & \multirow{4}{*}{$\begin{array}{c}24,6 \% \\
3,7 \%\end{array}$} \\
\hline Siprofloksasin & & \\
\hline Levofloksasin & & \\
\hline Golongan sefalosporin & & \\
\hline Seftriakson & 32 & $39,5 \%$ \\
\hline Sefotaksim & 17 & $20,9 \%$ \\
\hline Golongan penisillin & & \\
\hline Amoksisilin & 1 & $0,01 \%$ \\
\hline Ampisilin & 3 & $3,7 \%$ \\
\hline Golongan karbapenem & & \\
\hline Meropenem & 3 & $3,7 \%$ \\
\hline Golongan lain & & \\
\hline Sefobaktam & 2 & $0,02 \%$ \\
\hline Total & 81 & $100 \%$ \\
\hline
\end{tabular}

Tabel 2. Antibiotika Kombinasi yang diberikan pada pasien ISK di RSUD Kota Samarinda

\begin{tabular}{lc}
\hline \multicolumn{1}{c}{ Antibiotika } & Jumlah \\
\hline Ampisilin + sulbaktam & 8 \\
Seftriakson + siprofloksasin & 3 \\
Sefotaksim + gentamisin & 3 \\
Sefteiakson + metronidazol & 2 \\
Siprofloksasin + metronidazol & 1 \\
\hline Seftriakson + seterizin & 1 \\
Seftriakson + sefeksim & 1 \\
Seftriakson + ampisilin + & 1 \\
sulbaktam & \\
\hline Ampisilin + gentamisin & 1 \\
Amoksisilin + sefotaksim & 1 \\
\hline TOTAL & 22 \\
\hline
\end{tabular}


Pemilihan penggunaan antibiotika pada pasian infeksi dimana salah satunya ISK pada dasarnya harus dilakukan uji sensitivitas bakteri terlebih dahulu, untuk mengetahui mana antibiotika yang cocok dan sesuai untuk pasien. Namun tidak semua data rekam medik pasien terdapat hasil pemeriksaan uji sensitivitas bakteri.

\section{Penggunaan Antibiotika Terbanyak}

Tabel 3. Antibiotika Terapi ISK

\begin{tabular}{lccc}
\hline \multicolumn{1}{c}{ Antibiotika } & Rute & $\sum$ kasus & $\%$ \\
\hline Seftriakson & IV & 32 & 61,5 \\
Siprofloksasin & IV & 20 & 38,4 \\
\hline
\end{tabular}

Antibiotika seftriakson dan siprofloksasin merupakan antibiotika yang paling banyak digunakan pada terapi Infeksi Saluran Kemih (ISK) di RSUD Kota Samarinda. Hasil analisis menunjukan bahwa antibiotika seftriakson mencapai 32 kasus $(61,5 \%)$ dari seluruh terapi antibiotika, dan siprofloksasin mencapai 20 kasus $(38,4 \%)$ dari seluruh terapi antibiotika pada pasien ISK, sedangkan sisanya menggunakan antibiotika jenis lain. Penggunaan terapi antibiotika seftriakson dan siprofloksasin memiliki outcome klinis yang sama yaitu untuk menekan pertumbuhan bakteri namun memiliki mekanisme yang berbeda dimana seftriakson bekerja dengan menghambat dinding sel sedangkan siprofloksasin bekerja dengan cara mempengaruhi sintesis atau metabolisme asam nukleat [8].

Seftriakson adalah obat antibiotik beta-laktam golongan sefalosporin generasi ketiga berspektrum luas yang efek kerjanya dapat mencapai sistem saraf pusat. Seftriakson dapat digunakan secara intravena ataupun intramuskuler. Dalam $1 \mathrm{~g}$ seftriakson intravena terdapat sekitar $60-140 \mu \mathrm{g} / \mathrm{mL}$ seftriakson dalam serum. Obat golongan ini dapat melakuan penetrasi ke dalam jaringan, cairan tubuh, cairan serebrosinal serta dapat menghambat bakteri pathogen gram negatif dan positif [9].

Siprofloksasin termasuk antibiotik golongan kuinolon generasi kedua, dimana memiliki daya antibakteri terhadap gram negatif lebih kuat dibandingkan bakteri gram positif. Aktivitas siprofloksasin sangat efektiv dalam membunuh bakteri penyebab ISK, dengan mekanismenya yaitu menghambat replikasi DNA bakteri (inti sel bakteri) dengan cara menempel molekunya pada DNA girase (topoismerase II dan topoisomerase IV). Mekanisme yang langsung menuju intisel inilah yang menyebabkan bakteri dengan cepat dapat dieliminasi $[9,1]$.

\section{Analisis Biaya Minimal}

Penelitian ini dilakukan menggunaan ilmu Farmakoekonomi dengan pendekatan Cost Minimization Analysis (CMA). Studi CMA merupakan suatu metode analisis untuk membandingan 2 antibiotika yang memiliki biaya paling rendah, dimana dilakukan dengan cara menjumlahkan Direct Cost dan Indirect Cost. Direct Cost (DC) merupakan biaya yang langsung dikeluarkan oleh pasien berupa biaya obat, biaya kamar, kunjungan dokter, dan biaya pemeriksaan laboratorium, sedangkan Indirect Cost (IC) merupakan sejumlah biaya yang terkait dengan hilangnya produktivitas akibat menderita suatu penyakit. Nilai IC didapatkan dari nilai UMR atau Upah Minimal Regional, dimana pada Kota Samarinda sebesar Rp.2.654.894,-/bulan atau sebesar Rp.101.200,-/hari, nilai tersebut akan dikalikan dengan jumlah lama perawatan di Rumah Sakit, maka nilai tersebut merupakan nilai dari indiret Cost. 
Tabel 4. Hasil Analisis CMA

\begin{tabular}{cccc}
\hline AB & DC (Rp) & IC (Rp) & CMA(Rp) \\
\hline A & 50.857 .262 & 24.747 .636 & 3.600 .138 \\
B & 25.945 .000 & 14.04154 & 3.635 .140
\end{tabular}

Dari hasil perhitungan CMA didapatkan rata-rata biaya total perawatan per pasien kelompok antibiotika seftriakson lebih murah dibandingkan dengan kelompok antibiotika siprofloksasin atau dapat dikatakan lebih cost-minimalis. Rata-rata biaya total perawatan kelompok antibiotika seftriakson adalah sebesar Rp.3.600.138,sedangkan rata-rata biaya total perawatan kelompok antibiotika siprofloksasin sebesar Rp.3.635.140,-. Dalam penelitian sebelumnya di RSUP Prof. Dr. R. D. Kandou Kota Manado, menunjukan bahwa antibiotika yang terbanyak digunakan sama yaitu seftriakson dan siprofloksasin dengan perbandingan harga yang tidak berbeda jauh juga namun menunjukan bahwa seftriakson lebih cost minimalis dibandingkan dengan siprofloksasin [10].

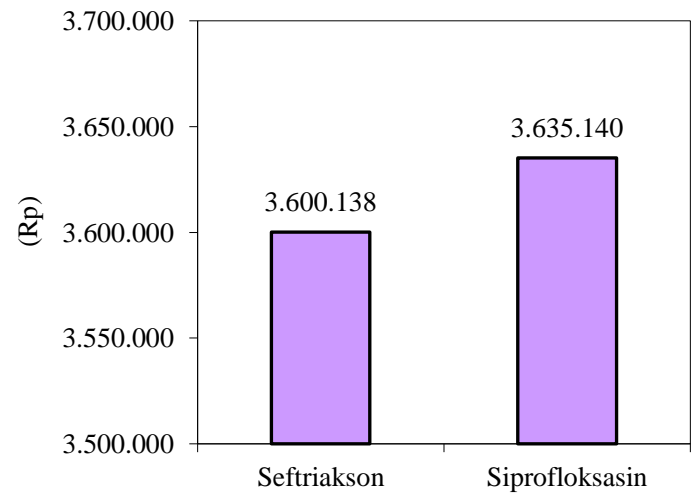

Gambar 4. Hasil Analisis CMA

Dari hasil analisis diperoleh nilai selisih dari kedua rata-rata biaya total perawatan sebesar Rp.35.002,-. Selisih tersebut dapat dikarenakan oleh beberapa hal, tetapi harga satuan antibiotika siprofloksasin yang lebih mahal dibandingkan harga satuan antibiotika seftriakson, memberikan kontribusi yang cukup dalam perbedaan tersebut. Selisih yang tidak terlalu signifikan ini membuat kedua antibiotika memiliki keefektivan yang cenderung sama, oleh karena itu perlu untuk dilakukan analisis lebih lanjut dengan metode CEA.

\section{KESIMPULAN}

Berdasarkan penelitian yang dilakukan terhadap pasien Infeksi Saluran Kemih (ISK) di beberapa RSUD Kota Samarinda periode Januari 2017 - Juni 2018 dapat diambil kesimpulan sebagai berikut:

1. Kelompok umur terbanyak penderita Infeksi Saluran Kemih berasal dari kelompok usia dewasa, dengan wanita lebih cenderung terkena dibanding pria.

2. Antibiotika yang paling banyak digunakan yaitu seftriakson dan siprofloksasin.

3. Seftriakson memiliki biaya lebih rendah atau lebih cost minimalis dibandingkan dengan siprofloksasin yaitu sebesar Rp.3.600.138,- dan Rp.3.635.140,-.

\section{DAFTAR PUSTAKA}

[1] Flores, Ana, L, and Walker, N. Jennifer. 2015. Urinary Tract Infections: Epidemiology, Mechanisms of Infection and Treatment Options. Macmillan Publishers Limited. Vol 13, No.1.

[2] WHO. 2001. WHO Model Prescribing Information: Drugs Used in Bacterial Infection. Geneva: WHO Press.

[3] Purnomo H. 2007. Dasar-Dasar Urologi, Edisi ke 2. Sangung Seto: Jakarta.

[4] Menkes RI. 2013. Pedoman Penerapan Kajian Farmakoekonomi. Direktorat Jenderal Bina Kefarmasian dan Alat Kesehatan. Jakarta. 
[5] Seputra, Kurnia. 2015. Guideline: Penatalaksanaan Infeksi Saluran Kemih dan Genitalia Pria Edisi ke-2 Tahun2015. Ikatan Ahli Urologi Indonesia (IAUI): Jakarta.

[6] Heisler, Christine, A., et al. 2008. Urinary Tract Infection in the Adult Female Pathophysiology, Evaluation, and Treatment. Fellows Lecture Series Journal of Pelvic Medicine \& Surgery Volume 14, Number 1.

[7] Gibson, John. 2003. Fisiologi \& Anatomi Modern untuk Perawat, Edisi 2. Penerbit Buku Kedokteran EGC: Jakarta.
[8] Kementrian Kesehatan RI. 2011. Pedoman Umum Penggunaan Antibiotika. Kemenkes RI: Jakarta.

[9] Triono, Afif dan Purwoko, Akhmad. 2012. Efektivitas Antibiotik Golongan Sefalosporin dan Kuinolon Terhadap Infeksi Saluran Kemih. Jurnal Mutiara Medika. Vol 12, No 1, hal 6-11.

[10] Inggrid, R.,R., Citraningtyas, G., \& Jonly, P., U. 2018. Analisis Efektivitas Biaya Pengobatan Infeksi Saluran Kemih Menggunakan Antibiotik Seftriakson dan Siprofloksasin di RSUP Prof. Dr. R. D Kandou. Jurnal Ilmiah Farmasi. Vol. 7 No. 3. 